\title{
PENGELOLAAN PEMBELAJARAN KURSUS DALAM MENUMBUHKAN KEMAMPUAN BERWIRAUSAHA LULUSAN KURSUS KOMPUTER DESAIN GRAFIS DI LKP IKMA MAJALAYA
}

\author{
Eneng Halimah Ariyandi, Asep Saepudin, Oong Komar \\ Universitas Pendidikan Indonesia \\ enenghalimahariyandi@upi.edu; asepsaefudin@upi.edu; oongkomar@upi.edu
}

\begin{abstract}
The background from this research because in the era of the business and industrial world today need human resources who competent and qualified. Today, many agencies are developing courses in Indonesia, one of the LKP IKMA Majalaya located in the district of Majalaya. IKMA is organizing various programs of courses, such as computer courses, accounting courses, and tutoring. IKMA also organizes community entrepreneurship program in cooperation with the government to reduce unemployment in the region of Majalaya. The program in the form of computer graphic design courses. This research aims to 1) describe the management learning courses in fostering entrepreneurship skills of graduates; 2) describe the entrepreneurship skills of graduates after the course; 3) know the supporting factor and inhibiting factor in fostering entrepreneurship skills of graduates. The method used is a descriptive method with qualitative approaches and techniques of collecting data through interviews, observation, and documentation. Subjects numbered four people consisting of one manager, one instructor and two graduates. Based on the processing of data and research results, obtained the following results. The First, activities of manager in management course learning to foster entrepreneurship skills of graduates include partnership building, provision of infrastructure and capital assistance for the graduate. The Second, emergence of entrepreneurship skills of graduates are characterized by traits entrepreneurs, namely confidence, task-oriented and results, risk-taking, leadership, originality and oriented to the future. Third, supporting factors consist of adequate infrastructure, and LKP has strategic locations. Furthermore, inhibiting factor consists of a shortage of human resources, especially instructors and prone to flooding.
\end{abstract}

Keywords: manager courses, graphic design, entrepreneur

\section{A. PENDAhULUAN}

Pada era dunia usaha dan dunia industri (DUDI) saat ini, diperlukan sumber daya manusia yang kompeten dan berkualitas serta dapat diandalkan oleh perusahaan/lembaga tertentu sebagai pendorong bagi perusahaan/lembaga untuk mendapatkan keuntungan yang sebesar-besarnya. Oleh karena itu, diperlukan sumber daya manusia yang memiliki nilai jual tinggi dan berkualitas agar perusahaan-perusahaan atau lembaga- lembaga tertentu tertarik dan berminat untuk merekrut mereka.

Berdasarkan Pusat Data Statistik Pendidikan Kemendikbud tahun 2014 jumlah anak putus sekolah (drop out) SMK/SMU/SMA ditambah lulusan SLTP, SLTA tidak melanjutkan ke pendidikan lebih tinggi tahun 2013 sebesar 2.023.222 anak. Sedangkan, menurut berita resmi statistik BPS pada tanggal 2 Januari 2015 menyatakan bahwa penduduk miskin di Indonesia pada 
September 2014 sebesar 27,73 juta jiwa atau sebesar 10,96\% dari total penduduk Indonesia. Begitu pula pada tanggal 5 November 2014, BPS menyatakan bahwa pengangguran terbuka di Indonesia pada Agustus 2014 sebesar 7,24 juta jiwa atau 5,94\% dari jumlah angkatan kerja sebesar 121,87 juta jiwa (Juknis PKH, 2015, hlm. 1). Permendikbud Nomor 81 Tahun 2013 Tentang Pendirian Satuan Pendidikan Nonformal Bab I Ketentuan Umum Pasal 1 butir ke empat menyatakan bahwa Lembaga Kursus dan Pelatihan selanjutnya disebut LKP adalah satuan pendidikan nonformal yang diselenggarakan bagi masyarakat yang memerlukan bekal pengetahuan, keterampilan, kecakapan hidup, dan sikap untuk mengembangkan diri, mengembangkan profesi, bekerja, usaha mandiri, dan/atau melanjutkan pendidikan ke jenjang yang lebih tinggi. Kursus merupakan satuan pendidikan luar sekolah, dimana kursus berfungsi sebagai penambah apabila masyarakat ingin menambah pengetahuan dibidang yang sama sehingga dengan mengikuti kursus diharapkan masyarakat memiliki bekal pengetahuan, keterampilan, kecakapan hidup dan sikap untuk mengembangkan diri, mengembangkan profesi, bekerja, usaha mandiri, dan/atau melanjutkan ke jenjang yang lebih tinggi. Selanjutnya, pada Pasal 1 Ayat (3) menyebutkan bahwa satuan PNF adalah kelompok layanan pendidikan yang menyelenggarakan program pendidikan nonformal.

Dihimpun dari website Direktorat Pembinaan Kursus dan Pelatihan Ditjen PAUDNI dan Dikmas Kemendikbud tentang program pendidikan kewirausahaan masyarakat, disebutkan dalam laporan penelitian World Economic Forum pada tahun 2011 yang bertajuk "The Global Entrepreneuralship and Successful Growth Strategies of Early Stage Companies", menunjukkan bahwa $1 \%$ dari total 380.000 perusahaan top dunia di 10 negara memberikan kontribusi sebesar 44\% dari total penghasilan mereka kepada negara dan 40\% memberikan lapangan kerja dan 5\% dari perusahaan-perusahaan teratas tersebut memberikan kontribusi $72 \%$ dari jumlah total penghasilan mereka dan 67\% terhadap penyediaan lapangan kerja. Oleh karena itu, pemerintah Indonesia mendorong tumbuhnya kewirausahaan masyarakat melalui program pendidikan kewirausahaan dalam bentuk regulasi dan implementasi di lapangan, diantaranya melalui Instruksi Presiden Nomor 6 Tahun 2009 tentang Pengembangan Ekonomi Kreatif. Presiden Republik Indonesia juga telah mencanangkan Gerakan Kewirausahaan Nasional pada Februari 2011. Melalui program kewirausahaan masyarakat ini diharapkan mampu mengurangi angka pengangguran yang menurut data BPS bulan Agustus 2011, jumlah penganggur terbuka tercatat sebanyak 7,7 juta orang $(6,56 \%)$ dari total angkatan kerja sekitar 117,37 juta orang. Dari jumlah tersebut sebagian besar berada di pedesaan. Jika dilihat dari latar belakang pendidikan para penganggur tersebut, 3,56\% berpendidikan SD ke bawah, 8,37\% berpendidikan SLTP, 10,66\% berpendidikan SMA, 10, 43\% berpendidikan SMK, 7,16\% berpendidikan Diploma, dan 8,02\% berpendidikan Sarjana.

LKP IKMA Majalaya merupakan salah satu LKP yang terdapat di Kabupaten Bandung tepatnya di Jalan Raya Laswi No. 203 Majalaya. LKP IKMA memiliki berbagai program yang diselenggarakan, yaitu kursus komputer, akuntansi, bahasa inggris dan bimbingan belajar. Pada kursus komputer, LKP IKMA menyediakan beberapa program, antara lain kursus komputer aplikasi perkantoran, kursus komputer desain grafis, kursus komputer pemograman, kursus komputer akuntansi, dan kursus komputer satu tahun/setara D1. LKP IKMA telah menyelenggarakan program kewirausahaan masyarakat pada tahun ini melalui kursus komputer desain grafis dan telah melahirkan 
lulusan yang kini membuka usaha sendiri atau berwirausaha dibidang desain grafis.

Berdasarkan penjabaran latar belakang masalah diatas dapat dirumuskan masalah penelitian ini yaitu 1) Kegiatan apa saja yang dilakukan pengelola dalam pengelolaan pembelajaran kursus agar menumbuhkan kemampuan berwirausaha lulusan komputer desain grafis di LKP IKMA Majalaya?; 2) Bagaimana kemampuan berwirausaha lulusan setelah mengikuti kursus komputer desain grafis di LKP IKMA Majalaya?; 3) Apa saja faktor pendukung dan faktor penghambat dalam menumbuhkan kemampuan berwirausaha lulusan kursus komputer desain grafis di LKP IKMA Majalaya?

\section{B. KAJIAN LITERATUR}

\section{Konsep Kursus}

\section{a. Pengertian Kursus}

Peraturan Menteri Pendidikan dan Kebudayaan Republik Indonesia Nomor 81 Tahun 2013 Tentang Pendirian Satuan Pendidikan Nonformal Bab I Ketentuan Umum Pasal 1 butir ke empat menyatakan bahwa Lembaga Kursus dan Pelatihan selanjutnya disebut LKP adalah satuan pendidikan nonformal yang diselenggarakan bagi masyarakat yang memerlukan bekal pengetahuan, keterampilan, kecakapan hidup, dan sikap untuk mengembangkan diri, mengembangkan profesi, bekerja, usaha mandiri, dan/atau melanjutkan pendidikan ke jenjang yang lebih tinggi. Lembaga kursus sebagai lembaga pendidikan luar sekolah (PLS) yang diprakarsai, dibiayai, dan diselenggarakan oleh masyarakat, baik secara perorangan, kelompok maupun komunitas yang melayani masyarakat dalam belajar guna mendapatkan pengetahuan, keterampilan (skill) fungsional, dan kecakapan hidup untuk mengembangkan diri, memperoleh pekerjaan, berusaha mandiri, ataupun melanjutkan ke jenjang pendidikan yang lebih tinggi. (Triyana, 2012, hlm. 14)

\section{b. Sistem Pembelajaran Kursus}

Menurut Komar (Komar, 2006, hlm. 203-204) salah satu pengertian sistem adalah sebagai suatu kesatuan yang terdiri atas berbagai komponen yang saling berkaitan secara terpadu untuk mencapai tujuan yang telah ditetapkan. Dengan demikian, sistem kegiatan pendidikan pada satuan kursus terdiri atas input, proses dan output. Input satuan kursus terbagi atas: input lingkungan (environmental input), input instrumen (instrumental input), input bahan mentah (raw input), dan input lain (other input). Di antara faktor yang merupakan input lingkungan adalah keadaan alam sekitar, lingkungan, keluarga, dan masyarakat, sosial ekonomi, biaya, sarana dan kebiasaan/tradisi.

Input instrumen satuan kursus terdiri dari tujuan, kurikulum, tenaga kependidikan, pembiayaan, sumber daya dan media belajar, fasilitas dan kondisi pengelola program. Input bahan mentah terdiri atas karakteristik internal dan eksternal warga belajar. Diantaranya menyangkut pengetahuan, pengalaman, keterampilan, kesiapan, motivasi, sosial ekonomi, biaya, sarana, dan kebiasaan belajar. Input lain merupakan faktor pendukung terhadap pengaktualisasian kemampuan yang telah diperoleh oleh warga belajar selama pendidikan berlangsung, seperti 
lapangan pekerjaan, permodalan, pemasaran, fasilitas informasi, kursus lanjutan, dan ikatan lulusan. Proses (troughput) yang terjadi di dalam satuan kursus merupakan fungsi dari peran serta dan bekerjanya faktor input (input lingkungan, instrumen, bahan mentah dan input lain). Selama proses berlangsung, bagi input bahan mentah akan terjadi pengentasan dalam bentuk pembelajaran, bimbingan, latihan dan interaksi lainnya yang memungkinkan terwujudnya perubahan pada pengetahuan, sikap, keterampilan dan kebiasaan warga belajar. Output satuan kursus berkenaan dengan produk dan dampak. Produk berhubungan dengan segala hal yang dihasilkan oleh kursus baik berkualitas maupun kuantitasnya serta barang dan jasa. Adapun dampak (outcome) berhubungan dengan konsekuensi ikatan yang melekat pada warga belajar setelah mengikuti pendidikan, seperti perubahan taraf hidup, penyebarluasan bahan belajar, serta peningkatan partisipasi sosial dalam pembangunan.

\section{Konsep Kewirausahaan}

\section{a. Pengertian Kewirausahaan}

Secara sederhana arti wirausahawan (enterpreneur) adalah orang yang berjiwa berani mengambil risiko untuk membuka usaha dalam berbagai kesempatan. Peter F. Drucker mengatakan bahwa kewirasuahaan merupakan kemampuan dalam menciptakan sesuatu yang baru dan berbeda. Sementara itu, Zimmerer mengartikan kewirausahaan sebagai suatu proses penerapan kreativitas dan inovasi dalam memecahkan persoalan dan menemukan peluang untuk memperbaiki kehidupan (usaha). (Kasmir, 2006, hlm. 16-17)

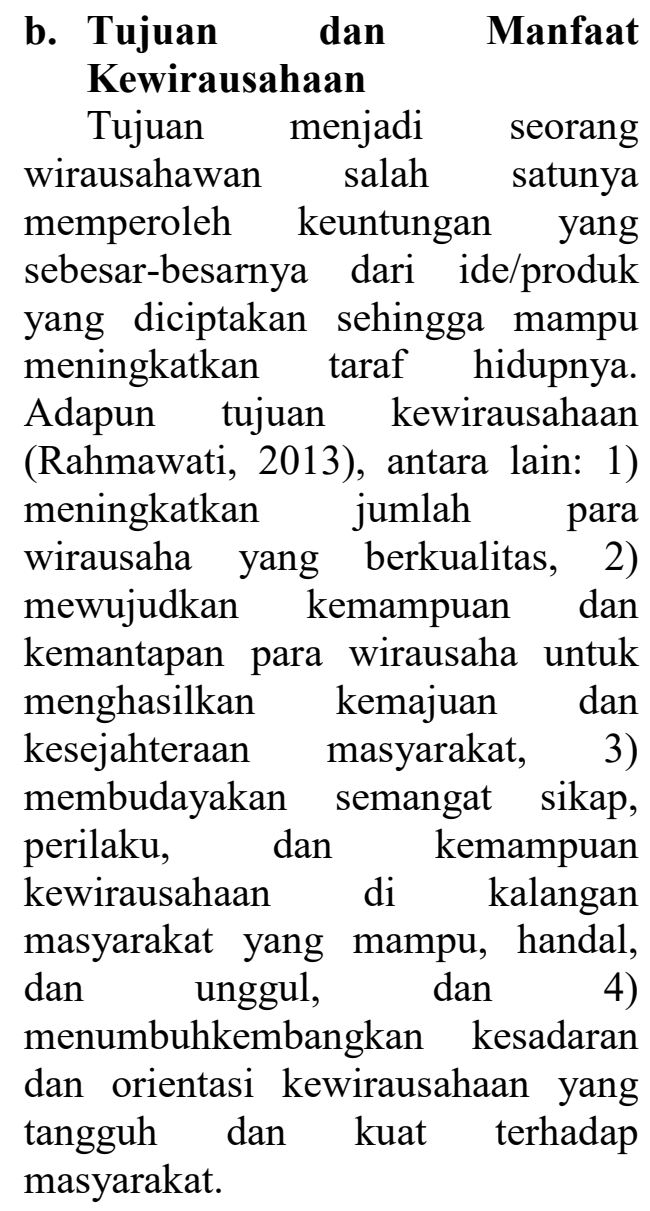

\section{c. Ciri-Ciri Wirausaha}

Menurut Meredith (2005) (dalam Bayu, 2010, hlm. 50-51), seorang wirausaha haruslah seorang yang mampu melihat ke depan, berpikir dengan penuh perhitungan, mencari pilihan dari berbagai alternatif masalah dan pemecahannya. Untuk menjadi seorang wirausaha tersebut seseorang harus memiliki karakter sebagaimana terlihat dalam Tabel 1. 


\section{Tabel 1}

Ciri-Ciri dan Watak/Karakter Wirausaha

\begin{tabular}{|c|c|}
\hline 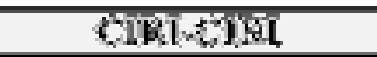 & 3ytak \\
\hline 919:menses & 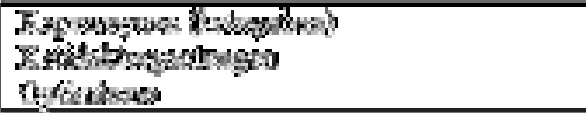 \\
\hline 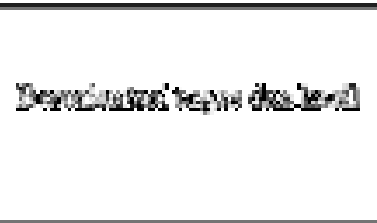 & 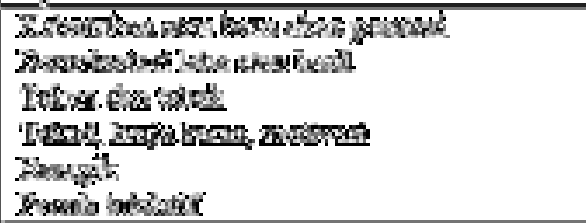 \\
\hline 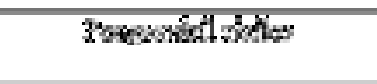 & 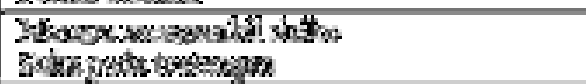 \\
\hline Espatinginst & 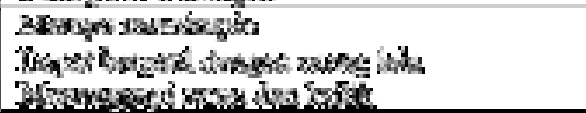 \\
\hline 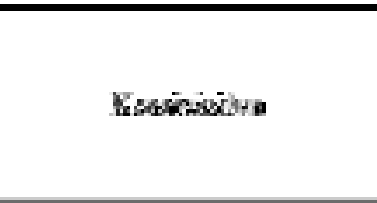 & 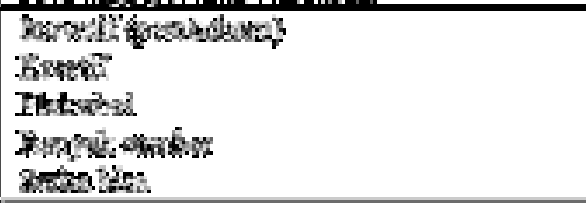 \\
\hline 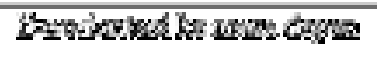 & 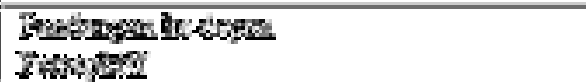 \\
\hline
\end{tabular}

Sumber: (Bayu, 2010, hlm. 50-51)

3. Pengelolaan Pembelajaran Kursus

\section{a. Kemitraan}

Jaringan kemitraan (Kamil, 2010, hlm. 166) adalah suatu strategi bisnis yang dilakukan oleh dua pihak atau lebih dalam jangka waktu tertentu untuk meraih keuntungan bersama dengan prinsip saling membutuhkan dan membesarkan. Keberhasilan kemitraan sangat ditentukan oleh adanya kepatuhan di antara yang bermitra dalam menjalankan etika bisnis. Menurut Kartasasmita (1996) (dalam Banowati, 2014, hlm. 31) kemitraan terutama dalam dunia usaha adalah hubungan antar pelakunya yang didasarkan pada ikatan usaha yang saling menguntungkan dalam hubungan kerja strategis, yang hasilnya bukanlah suatu zero-sum game, tetapi positive-sumgame atau win-win situation. Menurut
Kartasasmita (1996) (dalam Banowati, 2014, hlm. 33) dalam upaya mengembangkan dunia usaha, terdapat beberapa bentuk kemitraan yang dapat dikembangkan antara lain: 1) kemitraan antar skala usaha, 2) kemitraan usaha antar daerah tau antar kawasan, 3) kemitraan usaha antar sektor, dan 4) kemitraan dalam pengembangan sumber daya manusia (SDM) dan iptek.

\section{b. Kelengkapan Sarana dan Prasarana \\ Administrasi sarana dan} prasarana pendidikan merupakan seluruh proses kegiatan yang direncanakan dan diusahakan secara sengaja dan sungguhsungguhserta pembinaan secara kontinu terhadap benda-benda pendidikan, agar senantiasa siap-pakai (ready for use) dalam proses belajar mengajar 
sehingga proses belajar mengajar semakin efektif dan efisien guna membantu tercapainya

tujuan pendidikan yang telah ditetapkan. (Gunawan, 2002, hlm. 114) Secara otimologis (arti kata) (Daryanto, 2008, hlm. 51) prasarana berarti alat tidak langsung untuk mencapai tujuan. Dalam pendidikan, misalnya lokasi atau tempat, bangunan sekolah, lapangan olahraga, uang dan sebagainya. Sedangkan, sarana seperti alat langsung untuk mencapai tujuan pendidikan misalnya ruang kelas, buku, perpustakaan, laboratorium dan sebagainya. Sedangkan, menurut Keputusan Menteri $\mathrm{P}$ dan $\mathrm{K}$ No. 079/1975, sarana pendidikan terdiri dari 3 kelompok besar, yaitu: 1) bangunan dan perabot sekolah, 2) alat pelajaran yang terdiri dari pembukuan dan alat-alat peraga serta laboratorium, dan 3) media pendidikan yang dapat dikelompokkan menjadi audiovisual yang menggunakan alat penampil dan media yang tidak menggunakan alat penampil.

\section{c. Modal dan Strategi Kewirausahaan}

Dalam kewirausahaan, modal tidak selalu identik dengan modal yang berwujud (tangible) seperti uang dan barang, tetapi juga modal yang tidak berwujud (intangible) seperti modal intelektual, modal sosial, modal moral, dan modal mental yang dilandasi agama. Secara garis besar, modal kewiraushaan dapat dibagi ke dalam empat jenis (Riswari, 2014), yaitu:

1) Modal Intelektual. Modal intelektual dapat diwujudkan dalam bentuk ide-ide sebagai modal utama yang disertai pengetahuan, kemampuan, komitmen, dan tanggung jawab sebagai modal tambahan. Ide merupakan modal utama yang akan membentuk modal lainnya.

2) Modal Sosial dan Moral. Modal sosial dan moral diwujudkan dalam bentuk kejujuran dan kepercayaan, sehingga dapat membentuk sebuah kerjasama. Seorang wirausaha yang baik biasanya memiliki etika wirausaha seperti: (a) kejujuran; (b) memiliki integritas; (c) menepati janji; (d) kesetiaan; (e) kewajaran; (f) suka membantu orang lain; (g) menghormati orang lain; (h) warga negara yang baik dan taat hukum; (i) mengejar keunggulan; dan (j) bertanggung jawab. Dalam konteks ekonomi maupun sosial, kejujuran, integritas, dan ketepatan janji merupakan modal sosial yang dapat menumbuhkan kepercayaan dari waktu ke waktu.

3) Modal Mental. Modal mental adalah kesiapan mental berdasarkan landasan agama, diwujudkan dalam bentuk keberanian.

4) Modal Material. Modal material adalah modal dalam bentuk uang atau barang. Modal ini terbentuk apabila seseorang memilikijenisjenis modal di atas.

Dalam konsep strategi pemasaran terdapat istilah bauran 
pemasaran (marketing mix) yang dikenal dengan $4 \mathrm{P}$, yaitu barang dan jasa (product), harga (price), tempat (place), dan promosi (promotion). Dalam kewirausahaan, 4P tersebut ditambahkan satu $\mathrm{P}$, yaitu probe (penelitian dan pengembangan) sehingga menjadi 5P. Dalam riset pemasaran, probe selalu ditambahkan di awal sehingga urutan bauran pemasaran menjadi: a) probe (penelitian dan pengembangan); b) product (barang dan jasa); c) price (harga); d) place (tempat); dan e) promotion (promosi). Penelitian dan pengembangan dalam kewirausahaan merupakan strategi utama karena memiliki keterkaitan dengan kreativitas dan inovasi. Di dalamnya tercakup penelitian daan pengembangan produk, harga, tempat, dan promosi. Wirausaha berkembang dan berhasil karena memiliki kemampuan penelitian dan pengembangan yang memadai sehingga tercipta barang-barang yang bernilai dan unggul di pasar. (Riswari, 2014)

\section{METODOLOGI PENELITIAN}

Metode yang digunakan pada penelitian ini adalah metode deskriptif dengan menggunakan pendekatan kualitatif. Desain penelitian ini, terdiri dari tahap pralapangan, pelaksanaan dan pelaporan. Penentuan sumber data pada orang yang diwawancarai dilakukan secara purposive, yaitu dipilih dengan pertimbangan dan tujuan tertentu. Purposive sampling adalah teknik pengambilan sampel sumber data dengan pertimbangan tertentu (Sugiyono, 2015, hlm. 218-219). Sumber utama untuk memberikan informasi yang diperlukan peneliti, yaitu berjumlah sepuluh orang. Sepuluh orang tersebut merupakan lulusan kursus komputer desain grafis di LKP IKMA
Majalaya yang kini berwirausaha. Karena lulusan tersebut merupakan responden yang homogen atau sama berdasarkan kursus yang diikuti dan juga berwirausaha, maka peneliti bermaksud mengambil dua orang lulusan kursus komputer desain grafis yang berwirausaha. Kemudian, peneliti memilih partisipan berdasarkan beberapa pertimbangan antara lain partisipan terlibat secara langsung dalam penyelenggaraan kursus, mengetahui dan memahami tugas dan fungsi dalam penyelenggaraan kursus dan partisipan tersebut yang dianggap paling tahu tentang apa yang peneliti teliti yaitu pengelola dan instruktur kursus komputer desain grafis di LKP IKMA Majalaya.

Tempat penelitian yang akan dilaksanakan oleh peneliti, yaitu di LKP IKMA Majalaya yang bertempat di Jalan Raya Laswi No. 203 Majalaya. Peneliti memilih tempat penelitian tersebut karena LKP IKMA Majalaya menyelenggarakan kursus komputer yang dibagi lagi menjadi kursus komputer aplikasi perkantoran, desain grafis, pemograman, komputer akuntansi, dan kursus komputer 1 tahun (D1). Kursus yang akan menjadi fokus penelitian peneliti ialah kursus komputer desain grafis dan telah menjalin kerjasama dengan berbagai pihak, baik pemerintah maupun swasta, seperti LKP IKMA Majalaya telah menyelenggarakan program kursus komputer desain grafis bagi masyarakat kurang mampu melalui PKM (Program Kewirausahaan Masyarakat) Teknik pengumpulan data yang digunakan peneliti, yaitu wawancara, observasi, studi dokumentasi dan triangulasi data. Analisis data yang dilakukan oleh peneliti, yaitu reduksi data (data reduction), penyajian data (data display), dan penarikan kesimpulan dan verifikasi (conclusion drawing/verifying).

\section{HASIL DAN PEMBAHASAN}


1. Kegiatan Pengelola Dalam Pengelolaan Pembelajaran Kursus Agar Menumbuhkan Kemampuan Berwirausaha Lulusan Kursus Komputer Desain Grafis Di LKP IKMA Majalaya

Segi perencanaan yang dilakukan pengelola kursus sangat memperhatikan hal-hal penting dalam merencanakan dan menetapkan program kursus yang akan dilaksanakan, seperti adanya identifikasi kebutuhan kursus, merumuskan tujuan, perizinan pendirian lembaga, kelengkapan administrasi, sumber belajar, sumber dana, kualifikasi lulusan, penyebarluasan informasi, kemitraan, dan pengadaan fasilitas. Segi pelaksanaan, dapat disimpulkan bahwa pengelola kursus terlihat selalu menyesuaikan kurikulum yang ada dengan metoda pengajaran yang disesuaikan dengan kebutuhan lulusan serta perkembangan iptek. Penampilan instruktur pun diperhatikan oleh pengelola, mulai dari kesiapan instruktur sebelum melakukan proses pembelajaran di kelas, hal-hal yang harus dipersiapkan oleh instruktur sebelum mengajar, dan kompetensi instruktur dalam mengajar mulai dari cara berpakaian, cara mengajar, menguasai materi pembelajaran, dan bahasa yang digunakan ketika mengajar.Pada tahap evaluasi, dapat disimpulkan bahwa proses evaluasi yang dilaksanakan di LKP IKMA, yaitu penilaian terhadap proses pembelajaran dan pelaksanaan program. Aspek pembelajaran yang dievaluasi, meliputi pengetahuan, sikap dan keterampilan peserta. Evaluasi pembelajaran dilakukan melalui cara praktek langsung dan wawancara. Evaluasi pembelajaran dilaksanakan pada akhir kursus. Hasil pembelajaran yang diperoleh peserta memuaskan dan mampu mengoperasikan aplikasi desain grafis, seperti Corel Draw dan Photoshop. Namun, tidak ada kegiatan tindak lanjut dari hasil evaluasi pembelajaran yang dilaksanakan. Selanjutnya, evaluasi penyelenggaraan program kursus komputer desain grafis LKP IKMA dilaksanakan setiap sebulan sekali. Aspek yang dievaluasi mulai dari siswa, tenaga pengajar, kurikulum, staff maupun program kursusnya itu sendiri. Teknik evaluasi yang digunakan, yaitu dengan pertemuan sebulan sekali dengan staff di LKP IKMA membahas kekurangan dan kelebihan dari masing-masing aspek, maupun dari sarana prasarana dan layanan yang diberikan.

Hal di atas merupakan sebuah sistem, dimana sistem tersebut merupakan suatu kesatuan yang saling berkaitan guna mencapai tujuan yang telah ditetapkan. Oong Komar (Komar, 2006, hlm. 203-204) menyebutkan bahwa sistem adalah sebagai suatu kesatuan yang terdiri atas berbagai komponen yang saling berkaitan secara terpadu untuk mencapai tujuan yang telah ditetapkan. Dengan demikian, sistem kegiatan pendidikan pada satuan kursus terdiri atas input, proses dan output.

Adapun kegiatan lain yang khusus dilakukan oleh pengelola kursus dalam pengelolaan pembelajaran agar menumbuhkan kemampuan berwirausaha lulusan, diantaranya:

\section{a. Kemitraan}


Pengelola telah menjalin kerjasama dengan berbagai pihak, baik swasta maupun pemerintah. Tentunya kerjasama tersebut dapat menguntungkan satu sama lain, baik untuk lembaga maupun pihak yang bermitra. Hal ini sesuai dengan yang dikemukakan oleh Mustofa Kamil bahwa jaringan kemitraan (Kamil, 2010, hlm. 166) adalah suatu strategi bisnis yang dilakukan oleh dua pihak atau lebih dalam jangka waktu tertentu untuk meraih keuntungan bersama dengan prinsip saling membutuhkan dan membesarkan. Sedangkan, menurut Kartasasmita (1996) (dalam Banowati, 2014, hlm. 31) kemitraan terutama dalam dunia usaha adalah hubungan antar pelakunya yang didasarkan pada ikatan usaha yang saling menguntungkan dalam hubungan kerja strategis, yang hasilnya bukanlah suatu zero-sum game, tetapi positive-sumgame atau win-win situation.

Bentuk kerjasama yang dijalin LKP IKMA dengan pihak swasta berupa penyebarluasan informasi terkait lowongan pekerjaan, dan MOU yang tidak mengikat. Sedangkan kerjasama yang dijalin LKP IKMA dengan pihak pemerintah berupa program kursus singkat untuk masyarakat kurang mampu dalam rangka pemberian skill guna masyarakat menciptakan lapangan pekerjaan sendiri, IKMA hanya sebagai fasilitator dan pembiayaan seluruhnya berasal dari pemerintah. Kemitraan tersebut termasuk ke dalam bentuk kemitraan dalam pengembangan sumber daya manusia (SDM) dan iptek, yaitu pelaksanaan pelatihan sumber daya manusia dan bantuan teknologi bagi mitra yang dapat meningkatkan efektivitas dan keuntungan yang akan diperoleh dari kerjasama kemitraan.

\section{b. Kelengkapan Sarana dan Prasarana \\ Berdasarkan hasil} wawancara yang telah dilakukan kepada informan maka dapat disimpulkan bahwa pengelola kursus selalu berusaha memfasilitasi kebutuhan peserta kursus mulai dari pengadaan sarana dan prasarana yang memadai, sampai dengan menyiapkan instruktur yang kompeten dalam rangka menunjang pembelajaran dan peningkatan pengetahuan serta keterampilan peserta sehingga peserta terfasilitasi dan terlayani dengan baik. Penggunaan media pembelajaran pun dapat membantu peserta kursus dalam mepelajari materi kursus, seperti penggunaan modul pembelajaran dan akses internet. Hal ini sesuai yang dikemukakan oleh Daryanto (Daryanto, 2008, hlm. 51) prasarana berarti alat tidak langsung untuk mencapai tujuan. Dalam pendidikan, misalnya lokasi atau tempat, bangunan sekolah, lapangan olahraga, uang dan sebagainya. Sedangkan, sarana seperti alat langsung untuk mencapai tujuan pendidikan misalnya ruang kelas, buku, perpustakaan, laboratorium dan sebagainya. 
Sejalan dengan hal tersebut Gunawan menjelaskan administrasi sarana dan prasarana pendidikan merupakan seluruh proses kegiatan yang direncanakan dan diusahakan secara sengaja dan sungguhsungguh serta pembinaan secara kontinu terhadap benda-benda pendidikan, agar senantiasa siappakai (ready for use) dalam proses belajar mengajar sehingga proses belajar mengajar semakin efektif dan efisien guna membantu tercapainya tujuan pendidikan yang telah ditetapkan. (Gunawan, 2002, hlm. 114)

\section{c. Modal dan Strategi Kewirausahaan}

Modal yang digunakan oleh lulusan dalam berwirausaha terdiri dari ilmu yang diperoleh selama kursus tentang desain grafis, bantuan modal berupa peralatan desain seperti peralatan sablon, satu set komputer, dan printer. Dalam kewirausahaan, modal tidak selalu identik dengan modal yang berwujud (tangible) seperti uang dan barang, tetapi juga modal yang tidak berwujud (intangible) seperti modal intelektual, modal sosial, modal moral, dan modal mental yang dilandasi agama (Riswari, 2014).

Lulusan melakukan penelitian dan pengembangan produk yang akan dipasarkan melalui mengaplikasikan ilmu desain grafis yang telah diperoleh dan dikembangkan dengan menciptakan produk desain seperti mug, kaos, spanduk, dan lain sebagainya. Harganya pun terjangkau karena disesuaikan dengan keadaan ekonomi masyarakat sekitar. Usaha yang dijalankan lulusan bertempat di rumah mereka masingmasing. Promosi yang ditawarkan oleh lulusan dilakukan melalui media sosial, menawarkan secara langsung kepada masyarakat dan memasang spanduk. Lulusan pun tak segan untuk memberikan potongan harga kepada masyarakat sebagai media promosi khusunya untuk masyarakat yang ingin menjadi mitra kerja (reseller).

\section{Kemampuan Berwirausaha}

Lulusan Setelah Mengikuti Kursus Komputer Desain Grafis DI LKP IKMA Majalaya

a. Aspek Kognitif (Pengetahuan) Kognitif adalah ranah yang menekankan pada perubahan pengetahuan seseorang. Terdapat tiga tahapan yang ditekankan dalam penelitian ini, yaitu mengenai pengetahuan, pemahaman, dan penerapan. Lulusan mampu memahami langkah-langkah dalam mengoperasikan aplikasi komputer seperti Corel Draw dan Photoshop. Pengetahuan yang lulusan peroleh setelah mengikuti kursus diterapkan melalui berwirausaha dibidang desain grafis, diantaranya desain mug, spanduk dan kaos.

\section{b. Aspek Afektif (Sikap) \\ Afektif adalah ranah yang menekankan pada perubahan sikap dan pola pikir lulusan. Terdapat tiga tahapan yang ditekankan dalam penelitian ini, yaitu mengenai perubahan sikap yang dapat diterima lulusan, sikap dalam merespon}


instruktur dan menanggapi. Aspek afektif lulusan menunjukkan bahwa lulusan mengalami perubahan sikap, seperti lebih percaya diri akan kemampuan yang dimiliki, memiliki sopan santun, bersikap baik selama mengikuti kursus, mampu membantu teman sekelas apabila mengalami kesulitan dalam memahami materi, berperan aktif ketika kegiatan diskusi berlangsung, dan kegiatan kursus yang diikuti oleh lulusan memberikan banyak manfaat untuk dirinya.

\section{c. Aspek \\ Psikomotor (Keterampilan)}

Psikomotor merupakan ranah yang menekankan pada keterampilan lulusan. Aspek psikomotor lulusan menunjukkan bahwa lulusan memahami tentang ilmu desain grafis, mengoperasikan aplikasi pengolah gambar vektor dan gambar butmap seperti Corel Draw dan Photoshop. Keterampilan yang dikuasai oleh lulusan setelah mengikuti kursus komputer desain grafis diantaranya membuat desain untuk mug, kaos, spanduk, dan stiker.

\section{d. Kemampuan Berwirausaha}

\section{Kemampuan \\ Berwirausaha}

Kewiraushaan yang sudah berjalan yang dibentuk oleh lulusan IKMA berupa usaha dalam bidang percetakan, seperti cetak desain $m u g$, spanduk, dan kaos. Mereka membentuk usaha sendiri setelah mengikuti kursus komputer desain grafis di LKP IKMA. Dengan pengetahuan dan keterampilan yang diperoleh selama mengikuti kursus, usaha yang mereka dirikan memberikan keuntungan yang besar sehingga mereka mempunyai pendapatan sendiri dan dapat meningkatkan taraf hidup mereka.

Menurut Meredith (2005) (Bayu, 2010, hlm. 50-51), seorang wirausaha haruslah seorang yang mampu melihat ke depan, berpikir dengan penuh perhitungan, mencari pilihan dari berbagai alternatif masalah dan pemecahannya. Untuk menjadi seorang wirausaha tersebut seseorang harus memiliki karakter sebagai berikut:

1) Percaya diri. Lulusan menunjukkan percaya diri akan kemampuan yang dimiliki setelah mengikuti kursus. Hal ini diperoleh dari hasil penelitian bahwa lulusan dapat menjelaskan bagaimana langkah-langkah dalam membuat sebuah desain grafis, konsisten dengan usaha yang dijalankan karena lulusan menjalankan usaha secara sungguhsungguh dan usaha yang dijalankan sesuai dengan kemampuan yang dimilki setelah mengikuti kursus, yaitu desain grafis. Kemudian, usaha yang dijalankan oleh lulusan tidak tergantung dengan orang lain karena usaha yang dijalankan merupakan usaha sendiri dan dijalankan secara mandiri, tidak tergantung dengan orang lain.

2) Berorientasi tugas dan hasil. Hal ini diperoleh dari hasil penelitian bahwa setelah mengikuti kursus, peserta membutuhkan keterampilan lain agar dapat meningkatkan dan mengembangkan usaha yang dijalankannya seperti 
sablon dan fotografi. Lulusan tidak terlalu berorientasi pada laba atau hasil yang tinggi karena usaha yang dijalankan masih tergantung pada ada tidaknya pesanan dari konsumen, namun cukup untuk memenuhi kebutuhan seharihari lulusan. Lulusan sabar dan tabah dalam menjalankan usahanya, memiliki tekad yang kuat, energik dan bekerja keras dalam menjalankan usahanya. Cara yang dilakukan oleh lulusan dalam memajukan usahanya, yaitu melalui promosi yang dilakukan secara langsung maupun tidak langsung seperti door to door memberikan harga yang rendah/diskon, dan promosi melalui media sosial dan memasang spanduk.

3) Pengambil resiko. Lulusan berani menanggung risiko dalam menjalankan usahanya dengan cara memberikan harga di bawah harga pasar demi mempromosikan produknya. Lulusan suka pada tantangan karena dapat memperkuat mental dalam menjalankan usahanya. Kemudian, lulusan menciptakan inovasi yang berbeda dengan yang lain tanpa mengurangi kualutas produknya.

4) Kepemimpinan. Lulusan mampu menjalin jaringan usaha dengan menjalin jaringan usaha dengan reseller. Lulusan dapat bergaul dengan orang lain melalui proses menawarkan produk dengan cara santun dan lemah lembut supaya calon konsumen tertarik. Lulusan siap menanggapi saran dan kritik dan menerima dengan postif karena kritik dan saran menjadi perbaikan untuk kedepannya agar lebih baik lagi.

5) Keorisinilan. Lulusan mengikuti perkembangan zaman dan tren yang sedang ramai saat ini dalam memperbaharui produknya. Lulusan melakukan inovasi yang disesuaikan dengan perkembangan zaman dan tren yang sedang ramai saat ini. Banyak sumber yang dijadikan referensi oleh lulusan dalam menjalankan usahanya seperti melalui seminar, pelatihan dan internet. Lulusan tidak serba bisa dalam berbagai hal karena lulusan tidak memiliki keterampilan memperbaiki komputer, sablon dan fotografi.

6) Berorientasi ke masa depan. Lulusan memiliki rencana ke depan dalam memajukan usaha yang dijalankannya seperti memfasilitasi toko agar lebih komplit, membuat jaringan usaha (reseller), dan mempromosikan produk melalui media sosial maupun di dunia nyata.

3. Faktor Pendukung dan Faktor Penghambat Dalam Menumbuhkan Kemampuan Berwirausaha Lulusan Komputer Desain Grafis Di LKP IKMA Majalaya 
Berdasarkan hasil wawancara dengan informan $\mathrm{SJ}, \mathrm{IH}$, TP dan $\mathrm{NH}$, diperoleh data terkait faktor pendorong (kekuatan dan peluang) dan faktor penghambat (kelemahan dan ancaman) yang terdapat pada kursus komputer desain grafis LKP IKMA, diantaranya kekuatan terdiri dari program kursus beragam sesuai dengan kebutuhan saat ini, sarana dan prasarana pembelajaran memadai, fasilitas lengkap dan layak digunakan, dan lokasi kursus strategis. Kemudian, peluang terdiri dari kerjasama dengan berbagai pihak, baik swasta maupun pemerintah, kemajuan iptek dan Majalaya merupakan daerah industri. Sedangkan, kelemahan terdiri dari kekurangan SDM, khususnya instruktur, dan dekat dengan sungai Citarum. Selanjutnya, ancaman terdiri dari persaingan lembaga kursus dan pelatihan sejenis, dan rawan banjir. Keuntungan yang diperoleh dari kekuatan dan peluang adalah semakin banyak yang mengikuti kursus di LKP IKMA, membuka peluang untuk membuka usaha sendiri dan pbekerjasama dengan berbagai pihak dan penyerapan kerja lulusan semakin tinggi. Selanjutnya, solusi yang diperoleh dari kelemahan dan peluang adalah menjalin kerjasama dengan pihak swasta atau pemerintah perihal instruktur, seperti instruktur tamu/undangan maupun instruktur bantu dan memperbaharui fasilitas gedung tempat kursus agar terhindar dari banjir. Hasil yang diperoleh dari kekuatan dan ancaman, yaitu meningkatkan kualitas program kursus melalui akreditasi program kursus dan memperbaharui sarana dan prasarana yang disesuaikan dengan kebutuhan saat ini, seperti koneksi internet, software komputer, dan inovasi modul pembelajaran serta melakukan antisipasi jika datang musim hujan, seperti mempercepat waktu kursus dari biasanya agar terhindar dari banjir, dan merelokasi tempat kursus sementara apabila gedung tempat kursus terkena banjir. Selanjutnya, dari kelemahan dan ancaman diperoleh hasil, diantaranya persaingan lembaga kursus serupa semakin tinggi, jika biaya kursus mahal maka akan sedikit yang berminat mengikuti kursus, tempat kursus akan terendam banjir jika curah hujan tinggi serta tidak adanya inovasi akan mengurangi minat masyarakat mengikuti kursus.

\section{E. SIMPULAN DAN REKOMENDASI}

Pengelolaan pembelajaran kursus dalam menumbuhkan kemampuan berwirausaha lulusan kursus komputer desain grafis di LKP IKMA sudah maksimal. Kegiatan pengelolaan pembelajaran kursus yang dilakukan pengelola meliputi menjalin kemitraan dengan berbagai pihak seperti dinas pendidikan, dinas tenaga kerja, dan industri-industri yang berada di wilayah Majalaya. Kerjasama tersebut diantaranya penyelenggaraan program kursus dan penyebarluasan informasi terkait lowongan pekerjaan kepada LKP. Pengelola kursus juga berupaya memfasilitasi peserta kursus melalui pengadaan sarana dan prasarana yang memadai dan layak digunakan, seperti ruang kelas, modul pembelajaran, tempat praktek, perangkat komputer, aplikasi desain grafis, internet, infokus dan white board. Selanjutnya, prasarana yang disediakan oleh pengelola terdiri dari bangunan LKP, mushola, toilet, dan tempat parkir. Terdapat pemberian bantuan modal dari LKP untuk lulusan berupa peralatan 
desain seperti peralatan sablon, satu set komputer, dan printer. Aspek kognitif lulusan mengalami perubahan. Awalnya lulusan tidak mengetahui tentang desain grafis, namun setelah mengikuti kursus komputer desain grafis peserta mampu mengetahui konsep tentang desain grafis dan kewirausahaan. Aspek afektif lulusan menunjukkan bahwa lulusan mengalami perubahan sikap, seperti lebih percaya diri akan kemampuan yang dimiliki, memiliki sopan santun, dan bersikap baik selama mengikuti kursus. Aspek psikomotor lulusan menunjukkan bahwa lulusan memahami tentang ilmu desain grafis, mengoperasikan aplikasi pengolah gambar vektor dan gambar bitmap seperti Corel Draw dan Photoshop. Keterampilan yang dikuasai oleh lulusan setelah mengikuti kursus komputer desain grafis diantaranya membuat desain untuk mug, kaos, spanduk, dan stiker. Kemampuan berwirausaha lulusan terlihat dari rasa percaya diri, berorientasi pada tugas dan hasil, berani mengambil risiko, kepemimpinan, keorisinilan dan berorientasi ke masa depan.

Faktor pendukung dan penghambat dalam menumbuhkan kemampuan berwirausaha lulusan kursus komputer desain grafis di LKP IKMA Majalaya meliputi sarana dan prasarana yang memadai dan lokasi LKP yang strategis, dan faktor penghambat terdiri dari tidak adanya pendampingan terhadap lulusan, kekurangan SDM khusunya instruktur dan rawan banjir.

\section{DAFTAR PUSTAKA}

Banowati, R. (2014). Upaya Pengelola Lembaga Kursus Menjahit Dalam Mempersiapkan Lulusannya Memasuki Lapangan Kerja (Skripsi). Bandung: Universitas Pendidikan Indonesia.

Bayu, Y. S. (2010). Kewirausahaan Pendekatan

Karakteristik
Wirausahawan Sukses. Jakarta: Kencana.

Daryanto, H. (2008). Administrasi Pendidikan. Jakarta: PT Rineka Cipta.

Direktorat Pembinaan Kursus dan Pelatihan. (2015). Petunjuk Teknis Program Pendidikan Kecakapan Hidup. Jakarta: Direktorat Pembinaan Kursus dan Pelatihan.

Gunawan, A. H. (2002). Administrasi Sekolah (Administrasi Pendidikan Mikro). Jakarta: PT Rineka Cipta.

Instruksi Presiden Nomor 6 Tahun 2009 tentang Pengembangan Ekonomi Kreatif

Kamil, M. (2010). Model Pendidikan Dan Pelatihan (Konsep Dan Aplikasi). Bandung: Alfabeta.

Kasmir. (2006). Kewirausahaan. Jakarata: PT. Rajagrafindo Persada. Keputusan Menteri P dan K Nomor $079 / 1975$

Komar, O. (2006). Filsafat Pendidikan Nonformal. Bandung: CV. Pustaka Setia.

Pendidikan Kewirausahaan Masyarakat (PKM). (n.d.). Retrieved 12 28, 2016, from Direktorat Pembinaan Kursus dan Pelatihan: http://www.infokursus.net/pkbs.p hp?cat $=$ pkm

Peraturan Menteri Pendidikan dan Kebudayaan Republiki Indonesia Nomor 81 Tahun 2013 tentang Pendirian Satuan Pendidikan Nonformal.

Riswari, A. (2014, 03 05). Menumbuhkan Semangat Kewirausahaan Dan Membangun Kepedulian Terhadap Ekonomi Kerakyatan. Retrieved 10 20, 2016, from Asal Posting: http://anawari.blogspot.co.id/2014 /03/menumbuhkansemangatkewirausahaan-dan.html 
Rahmawati, F. (2013, 01 08). Asas, Tujuan, dan Manfaat Kewirausahaan. Retrieved 10 20, 2016, from Kewirausahaan:

http://industri18fajrirahmawati.bl ogspot.co.id/2013/01/asastujuandan-manfaatkewirausahaan.html

BIBLIOGRAPHY Sugiyono. (2015). Penelitian Kuantitatif Kualutatif Dan $R \& D$. Bandung: CV. Alfabeta.

Triyana, Y. F. (2012). Tips Merintis Dan Mengelola Berbagai Lembaga Kursus. Yogyakarta: Laksana. 